\title{
Spatial distribution of heavy metals and arsenic in soils of Aragón (NE Spain): controlling factors and environmental implications.
}

Ana Navas and Javier Machín.

Departamento de Edafología. Estación Experimental de Aula Dei. CSIC.

Apartado 202. 50.080. Zaragoza. Spain.

Phone: 3476 576511.Fax: 3476 575620. anavas@eead.csic.es

\begin{abstract}
Legal regulation of heavy metal contents is a main issue in many European countries, where still do not exist laws establishing the heavy metal levels permitted in soils. As a first step to determine the reference levels of heavy metals, it is required to know their contents in soils under natural conditions. To achieve this goal in the Autonomous Community of Aragón, a total of 133 sites have been sampled. A balanced allotment of the sampling sites, according to soil spatial distribution in the region, has been carried out by selecting 9 soil types that represent $97.5 \%$ of its surface area. Fifteen elements ( $\mathrm{Cr}, \mathrm{Cu}, \mathrm{Ba}, \mathrm{As}, \mathrm{Sb}, \mathrm{Hg}, \mathrm{Sn}, \mathrm{Mn}, \mathrm{Fe}, \mathrm{Al}, \mathrm{Zn}, \mathrm{Ni}, \mathrm{Co}, \mathrm{Cd}$ and $\mathrm{Pb}$ ) have been analysed by ICP-AES after a partial acid extraction.

The content of analysed elements has been correlated to some soil parameters such as organic matter, $\mathrm{pH}$, and granulometric fractions. Results of the statistical analyses have shown a large variety and complexity in some of these relationships. The main factors of variation in the heavy metal contents are both the soil type and the lithology. Gypsisols and Calcisols developed on sedimentary rocks have the lowest contents while Leptosols overlying metamorphic and igneous rocks have the highest contents. The spatial distribution of heavy metal contents shows a large variability with the highest contents in the mountain ranges (Iberian and Pyrenees) and the lowest in the plains of the central Ebro valley.
\end{abstract}

Key words: Heavy metals. Base levels. Natural soils. Spatial distribution. Geochemical mapping. GIS. Aragón. NE Spain. 


\section{1.- Introduction}

Soils are prone to contamination from atmospheric and hydrological sources, but direct waste disposal causes a major impact on this natural resource, posing serious environmental concerns. Regional geochemical surveys have been frequently used in mineral exploration (e.g. Rose et al., 1979), but current interest in these surveys is their application to environmental and pollution studies (e.g. Webb et al., 1978). Although many geochemical maps have been produced based on the analysis of rocks and stream sediments, similar maps based on soil analysis are rather less frequent (Kinniburgh \& Beckett, 1983; McGrath \& Loveland, 1992; Jordan et al., 1997). Nevertheless, these studies are increasingly considered of interest to establish the environmental levels of various heavy metals in order to outline areas of potential toxicity. Also information on the soil macro and micronutrient levels and trace elements could be of great interest for agricultural use (Wilcke et al., 1998) as well as for resource identification and management and land use planning.

Around the world several studies have evaluated the heavy metals concentration in soils (Kabata-Pendias \& Pendias, 1984; Brümmner et al., 1986; Wopereis, et al., 1988; Vaselli et al., 1997). Nevertheless in Aragón, such studies are non-existent to date and therefore, very little is known about the distribution of such elements in the natural, non anthopogeneic and non polluted soils of this territory. For this reason, this study was aimed to provide a contribution to a data-base on the heavy metal status natural background- of the main soil types in this region as basis for a wide variety of economic and environmental applications, as well as an approach to assess the relationship between geochemistry and the health of ecosystems.

\section{2.- Material and methods}

\subsection{Study area}

The Aragón Autonomy, located in the central part of the Ebro basin (NE Spain), extends over $45,000 \mathrm{~km}^{2}$ in the central Ebro basin (NE Spain) and exhibits a variety of soils developed on diverse lithologies and under a wide range of climatic conditions. The Pyrenees and the Iberian range that extend to the North and South respectively, surround the Ebro depression and characterize the geological context of this region 
(Figure 1). In the axial Pyrenees, granitic, metamorphic and some minor volcanic rocks are found. Such materials are less abundant in the Iberian range where only some metamorphic and subvolcanic rocks appear. The sedimentary sequence in both ranges extends from the Palaeozoic to the Mesozoic, with predominant calcareous rocks. From the borders of the ranges to the centre of the Ebro valley there is a gradation from clastic materials -conglomerates, sand, silt and clay- to marls and carbonatic rocks and finally evaporitic rocks such as gypsum and halite, in the centre of the valley, in the Zaragoza area.

The physiography of the region displays a high variety. Contrasted landscapes, from the alpine environment in the Pyrenees, the middle mountain landscapes and the semidesertic central plains are found. This diversity is paralleled with the distribution of the vegetation that ranges from the dense temperate forest to the scarce shrubby vegetation of the central valley. Climate is very diverse from the semiarid Mediterranean in the centre of the valley to the more temperate and humid continental climate in the ranges. Therefore, a marked gradient in both temperature and annual rainfall distribution from the centre of the valley towards the mountains is evident (Figure 1).

The important diversity in parent materials along with the climatic and geomorphic features have conditioned the development of a wide variety of soil types. From the Soil Map of Aragón (Machín, 1984), a total of 32 main groups of soils have been classified according to FAO (1989). Of those, a total of 9 soil types have been selected as the most representative on the basis of their surface extension and spatial distribution in the region to conduct our soil survey.

\subsection{Soil sites and sampling}

Sampling sites were distributed to include a representative variety of each soil type and sampling density was 1 sample each $338 \mathrm{~km}^{2}$. The sampling site pattern is aimed to proportionally distribute, among the selected soil types, a number of samples in accordance with the surface occupied by each soil type and its spatial variability. To achieve this, parent materials, vegetation cover, geomorphology and climate have been carefully examined. Nine different soil types representing $97.5 \%$ of the Aragón total surface area have been selected for this study. A summary of the selected soil types and the corresponding sample allotment is presented in Table 1. 
A total of 133 sampling sites not affected by anthropogenic activities were chosen for their edaphic significance. For this, it was taken into account that sites should represent the most relevant characteristics of the morpho-edaphic environment of each soil type. The sampling procedure intended to obtain a representative average sample made of five sub-samples collected at each site. Therefore, a number of 133 soil samples were composed from a total of 665 soil sub-samples collected. Samples were extracted by using an automatic core driller. In most soils, depth of sampling was around $40-50 \mathrm{~cm}$. In order to try to obtain background levels for the analysed elements, the chosen sampling sites were far from any visible or known local source of pollutants, and agricultural and urban soils were avoided.

\section{3.- Analytical methods}

Soil samples $(\mathrm{n}=133)$ were air-dried, and crushed to pass through a $2 \mathrm{~mm}$ sieve. Each sample was homogeneized and quartered and ground in an agate mortar.

Samples have been analysed for 15 elements, of which apart from Ba (light metal) and $\mathrm{As}$ (metalloid), the following 13 elements are heavy metals: $\mathrm{Cr}, \mathrm{Cu}, \mathrm{Sb}, \mathrm{Hg}$, $\mathrm{Sn}, \mathrm{Mn}, \mathrm{Fe}, \mathrm{Al}, \mathrm{Zn}, \mathrm{Ni}, \mathrm{Co}, \mathrm{Cd}$ and $\mathrm{Pb}$. Analysis were performed by atomic emission spectrometry using an inductively coupled plasma ICP-AES (JY 98), after a partial acid digestion ( $5 \mathrm{ml} \mathrm{HNO}_{3} 65 \%, 1 \mathrm{ml} \mathrm{H}_{2} \mathrm{O}_{2} 30 \%$ ) in microwave (Milestone mls). This method was chosen as previous work confirmed that it was a good extractant for most of the elements. Hydride generation (CMA Lab Craft Hydri S-05) has been used to analyse $\mathrm{Hg}, \mathrm{As}, \mathrm{Sb}$ and $\mathrm{Sn}$. Contents, obtained after three measurements per element, are expressed in $\mathrm{mg} / \mathrm{kg}$. Detection limits for the elements that in some samples were below detection limits are (in ppb): Cd: 25, Co: 40, Sn: 55, Hg: 45, As: 50, Sb: 60, Pb: 55 . Hg has non been detected in any sample of the studied soils. Sn was not detected in 33 samples and $\mathrm{Sb}$ has only been detected in 8 samples. As quality control, duplicate analyses as well as analyses at an external laboratory were performed on 13 selected samples.

Granulometric analysis of fine silt $(2-5 \mu)$ and clay $(<2 \mu)$ size fractions were performed using Coulter laser equipment. Samples were stirred and ultrasound used to facilitate particle dispersion. $\mathrm{pH}$ (1:2.5 soil:water) was measured using an Orion 901 $\mathrm{pH}$-meter. Organic matter was determined by the Sanerlandt method using a Mettler 
Toledo titrimeter and electrode. Cation exchange capacity (CEC) was analysed using the method of Polemio \& Rhoades (1977).

\section{4.- Data processing}

The relationships between the analysed heavy metals and between some soil parameters and the heavy metals have been assessed. Furthermore, the influence of soil and lithology types on the metal contents has been analysed through an ANOVA test.

Maps of isolevels of heavy metal contents have been produced as a first approach to know their spatial distribution in the studied soils. A raster-based GIS has been used to integrate physiographic, lithologic and soil information and to produce a number of combinations of output data that resulted in several thematic maps. Thus, the spatial distribution of heavy metals in the soils of Aragón has been mapped by geostatistical interpolation. Two-dimensional ordinary block kriging as a most advantageous interpolation technique was applied to produce regular grids.

Geographical information systems are increasingly being used for producing thematic maps (Burrough, 1986; Berry, 1987; Rogowski, 1996). Our database includes: topography at 1/200,000 scale, map of soils at 1/500,000 scale, map of mean annual precipitation $(\mathrm{mm})$ and soil profile descriptions and associated data. The digitized topography of Aragón $(1 / 200,000)$ was used to build up a digital elevation model of the area with Surfer, a program linked to IDRISI GIS. A vector-based computer-aided design package (AutoCAD) has been used for digitizing lithology and soil types $(1 / 500,000)$. MicroStation software (I/GEOVEC) was used for geographic vectorization of map features. Output images were processed with CorelDRAW. Hardware platform was on Pentium 160 32Mb RAM.

\section{Results}

A summary statistics for the analysed elements in all the studied samples are presented in Table 2. Hg has not been detected in any of the studied samples and $\mathrm{Sb}$ is only detected in eight of them and consequently data from these elements are not presented in Table 2. $\mathrm{Cu}, \mathrm{Co}, \mathrm{Sn}, \mathrm{As}$ and $\mathrm{Pb}$ present arithmetic mean contents of around $10 \mathrm{mg} / \mathrm{kg}$. Cr and $\mathrm{Ni}$ around $20 \mathrm{mg} / \mathrm{kg}$, Zn of $56 \mathrm{mg} / \mathrm{kg}, \mathrm{Ba}$ around $110 \mathrm{mg} / \mathrm{kg}$, Mn around $320 \mathrm{mg} / \mathrm{kg}$. Cd has the lowest mean concentration $(0.75 \mathrm{mg} / \mathrm{kg})$, while the 
highest contents are in Fe $(16868 \mathrm{mg} / \mathrm{kg})$ and $\mathrm{Al}(19977 \mathrm{mg} / \mathrm{kg})$. The coefficients of variation vary from $44 \%(\mathrm{Al})$ to $228 \%(\mathrm{Sn})$.

A measure of the analysed elements is shown for each of the studied soil types in the box and whisker plots of Figures 2 and 3. Because there is no data base to compare the heavy metal contents in the studied samples with other findings in the region, we compared the contents of some heavy metals with those reported for other natural soils such as in East and South Spain, and other temperate soils in USA, France and Australia. We use the median as preferred statistical value than the arithmetic mean because it is not dependent on outliers.

The median $\mathrm{Cr}$ content calculated for each studied soil type, range between 12 $\mathrm{mg} / \mathrm{kg}$ (Gypsisols) and $26 \mathrm{mg} / \mathrm{kg}$ (Leptosols). Most soils have $\mathrm{Cr}$ contents below 19 $\mathrm{mg} / \mathrm{kg}$. Phaeozems and Kastanozems have median contents around $21 \mathrm{mg} / \mathrm{kg}$.

Median $\mathrm{Cu}$ ranges between 5 and $13 \mathrm{mg} / \mathrm{kg}$ in Gypsisols and Phaeozems respectively. Most soils have $\mathrm{Cu}$ contents below $10 \mathrm{mg} / \mathrm{kg}$. These contents are very similar to mean values of $13 \mathrm{mg} / \mathrm{kg}$ extracted after partial acid digestion in a variety of natural soils of Valencia (Spain) as reported by Boluda Hernández et al. (1988). Low $\mathrm{Cu}$ values (around $6 \mathrm{mg} / \mathrm{kg}$ ) occur in Calcisols. Contents around $12 \mathrm{mg} / \mathrm{kg}$ are found in Leptosols.

Median $\mathrm{Pb}$ contents vary between $4 \mathrm{mg} / \mathrm{kg}$ (Gypsisols and Calcisols) and 14 $\mathrm{mg} / \mathrm{kg}$ found in Leptosols. According to Boluda Hernández et al. (1988), a range between 10 and $67 \mathrm{mg} / \mathrm{kg}$ is frequent in soils of the world. Other low values (around 5 $\mathrm{mg} / \mathrm{kg}$ ) occur in Cambisols and Regosols. Most soils have $\mathrm{Pb}$ contents below $8 \mathrm{mg} / \mathrm{kg}$. Other relatively high values (around $10 \mathrm{mg} / \mathrm{kg}$ ) are found in Fluvisols.

Median Ni ranges between $9 \mathrm{mg} / \mathrm{kg}$ in Gypsisols and $21 \mathrm{mg} / \mathrm{kg}$ found in Leptosols and Solonchaks. The rest of the studied soils have $\mathrm{Ni}$ contents around 18 $\mathrm{mg} / \mathrm{kg}$ and do not show much variability. Although higher Ni contents (around 50 $\mathrm{mg} / \mathrm{kg}$ ) are recorded in the literature (Kabata Pendias \& Pendias, 1984), our values are similar to those found in Rendzic Leptosols of Australia by McKenzie (1959).

Median Sn contents vary between $0.85 \mathrm{mg} / \mathrm{kg}$ (Fluvisols) and $3.4 \mathrm{mg} / \mathrm{kg}$ in Leptosols. Most of the Gypsisols samples show Sn contents below the detection limit (55 ppb).

Median Co contents vary between $2 \mathrm{mg} / \mathrm{kg}$ in Gypsisols and $9 \mathrm{mg} / \mathrm{kg}$ found in Leptosols. Most soils have Co contents around $6 \mathrm{mg} / \mathrm{kg}$. Similar Co contents (10 mg/kg) 
have been measured in Leptosols and Calcisols of South Spain by González García \& García Gómez (1964).

Median Zn contents vary from 26 to $68 \mathrm{mg} / \mathrm{kg}$ in Gypsisols and Leptosols, respectively. Most of the studied soils have $\mathrm{Zn}$ contents around $46 \mathrm{mg} / \mathrm{kg}$. A wide range of variation in the soil $\mathrm{Zn}$ content has been indicated by Aubert \& Pinta (1977).

$\mathrm{Cd}$ presents a high variability in most of the studied soils. The 5 Phaeozem samples show $\mathrm{Cd}$ contents below the detection limit but for most of the studied soils, median contents of around $0.50 \mathrm{mg} / \mathrm{kg}$ are in close agreement with data $(0.50 \mathrm{mg} / \mathrm{kg})$ from Kabata Pendias \& Pendias (1984). The highest median value was found in Leptosols $(1.4 \mathrm{mg} / \mathrm{kg})$. High Cd values $(1.9-3.4 \mathrm{mg} / \mathrm{kg})$ have been found in calcareous mountain soils of Valencia (Boluda Hernández et al., 1988).

Ba contents vary between $81 \mathrm{mg} / \mathrm{kg}$ (Regosols) and $117 \mathrm{mg} / \mathrm{kg}$ (Cambisols). Most soils have Ba contents around $90 \mathrm{mg} / \mathrm{kg}$. Median As contents range between 6 and $17 \mathrm{mg} / \mathrm{kg}$ found in Calcisols and Leptosols respectively. Most soils have As contents around $13 \mathrm{mg} / \mathrm{kg}$.

$\mathrm{Sb}$ has only been detected in very few samples of 4 of the studied soil types: Fluvisols, Gypsisols, Leptosols and Cambisols. The highest value $(68.3 \mathrm{mg} / \mathrm{kg})$ is found in Leptosols.

$\mathrm{Fe}, \mathrm{Al}$ and $\mathrm{Mn}$ show large differences in their median contents among the studied soil types. Fe contents vary between 7940 and $19160 \mathrm{mg} / \mathrm{kg}$ found in Gypsisols and Kastanozems, respectively. Al contents range between 10370 and $25410 \mathrm{mg} / \mathrm{kg}$ found in Gypsisols and Phaeozems respectively. Most soils have Fe and Al values of $17000 \mathrm{mg} / \mathrm{kg}$. Mn contents vary between 153 and $399 \mathrm{mg} / \mathrm{kg}$ also found in Gypsisols and Solonchaks respectively and most soils have median contents of $250 \mathrm{mg} / \mathrm{kg}$.

In general, the heavy metal contents are highly variable in Leptosols that exhibit the highest coefficient of variation for $\mathrm{Cr}, \mathrm{Cu}, \mathrm{Ni}, \mathrm{Co}$ and $\mathrm{Mn}$. $\mathrm{Pb}, \mathrm{Zn}$ and $\mathrm{Ba}$ are highly variable in Cambisols as As and Fe are in Regosols and Al in Kastanozems.

To examine the relationships between the analysed elements, a correlation table (Pearson and Spearman correlation coefficients) has been established. The table was computed from the 133 samples set (Table 3). According to Pearson R most heavy metals were directly and significantly correlated although the correlations were not significant between $\mathrm{Ni}$ and $\mathrm{As}, \mathrm{Pb}$; between $\mathrm{Sb}$ and $\mathrm{Cr}, \mathrm{Zn}, \mathrm{As}, \mathrm{Pb}, \mathrm{Al}, \mathrm{Mn}$; between $\mathrm{Sn}$ and the rest of elements and between $\mathrm{Ba}$ and the rest of elements. 
The Spearman coefficients have also been computed from the rank of the data values because they are less sensitive to outliers than the Pearson coefficients. According Spearman R (Table 3) there are: (1) highly significant $(\mathrm{p} \leq 0.001)$ positive correlations between $\mathrm{Cr}$ and $\mathrm{Cu}, \mathrm{Ba}, \mathrm{Cd}, \mathrm{Co}, \mathrm{Zn}, \mathrm{Ni}, \mathrm{As}, \mathrm{Pb}, \mathrm{Fe}, \mathrm{Al}, \mathrm{Mn}$; (2) significant positive correlations $(\mathrm{p} \leq 0.01)$ between $\mathrm{As}$ and $\mathrm{Cd}, \mathrm{Ba}$; (3) significant positive correlations $(\mathrm{p} \leq 0.05)$ between $\mathrm{Cd}$ and Al. The correlations were not significant between $\mathrm{Ba}$ and $\mathrm{Cd}$ and between $\mathrm{Sn}$ and $\mathrm{Sb}$ with the rest of elements because both heavy metals were not detected in a significant number of samples.

In general higher values of correlation coefficients are obtained from Spearman $\mathrm{R}$ for most heavy metals. From these results it can be said that the heavy metals are directly and significantly related between themselves.

\section{1.- Relationships with soil parameters and controlling factors.}

As it is widely recognized in the literature there are a number of physical and chemical properties of soils affecting metal mobilization-inmobilization processes (Jones and Jarvis, 1981). In the samples of the studied soils mean $\mathrm{pH}$ is 8.05 and values range from 5.86 to 9.31 and the coefficient of variation $(\mathrm{CV})$ is $7 \%$. Mean organic matter is $2.8 \%$ and varies between $0.17 \%$ and $12.36 \%(\mathrm{CV}: 76 \%)$. The mean cation exchange capacity is $25 \mathrm{meq} / 100 \mathrm{~g}$ and ranges from 18 to $33 \mathrm{meq} / 100 \mathrm{~g}(\mathrm{CV}: 14 \%)$. The mean clay content is $15 \%$ and varies between $1.5 \%$ and $30 \%(\mathrm{CV}: 44 \%)$ and the mean fine silt is $13 \%$ and varies between $1.6 \%$ and $31 \%(\mathrm{CV}: 46 \%)$. The spatial distribution of these soil properties can be seen in Figure 4.

To analyse the relationships between these soil parameters and the heavy metal contents, a Pearson R correlation analysis has been applied to the 133 sample set of the studied soils. As can be seen in Table 4, between the organic matter percentage and the heavy metal contents there are: 1) significant positive correlations with $\mathrm{Cr}, \mathrm{Co}, \mathrm{Zn}, \mathrm{Sn}$, $\mathrm{As}, \mathrm{Pb}, \mathrm{Fe}, \mathrm{Al}$ and $\mathrm{Mn}$; 2) no significant correlations with $\mathrm{Cu}, \mathrm{Cd}, \mathrm{Ba}, \mathrm{Ni}$ and $\mathrm{Sb}$.

Between the cation exchange capacity (CEC) and the heavy metal contents there are: 1) significant and positive correlations with $\mathrm{Cr}, \mathrm{Co}, \mathrm{Zn}, \mathrm{Ni}, \mathrm{As}, \mathrm{Pb}, \mathrm{Fe}, \mathrm{Al}$ and $\mathrm{Mn}$; 2) no significant correlations with $\mathrm{Cu}, \mathrm{Cd}, \mathrm{Ba}, \mathrm{Sn}$ and $\mathrm{Sb}$. Between $\mathrm{pH}$ and the heavy metal contents there are: 1) significant and negative correlations with $\mathrm{Cu}, \mathrm{Cd}$, $\mathrm{Ba}, \mathrm{Co}, \mathrm{Zn}, \mathrm{As}, \mathrm{Pb}, \mathrm{Fe}$ and $\mathrm{Mn}$; 2) no significant correlations with $\mathrm{Cr}, \mathrm{Sn}, \mathrm{Ni}, \mathrm{Sb}$ and Al. 
Between the clay percentage and the heavy metal contents there are: 1) significant positive correlations with $\mathrm{Cr}$, As and $\mathrm{Al}$; 2) significant negative correlations with $\mathrm{Cd}$ and $\mathrm{Sb} ; 3$ ) no significant correlations with $\mathrm{Cr}, \mathrm{Ba}, \mathrm{Co}, \mathrm{Zn}, \mathrm{Sn}, \mathrm{Ni}, \mathrm{Pb}, \mathrm{Fe}$ and Mn. Between the fine silt percentage and the heavy metal contents there are: 1) significant positive correlations with $\mathrm{Cr}$, $\mathrm{As}, \mathrm{Al}$ and $\mathrm{Mn}$; 2) a significant negative correlation with $\mathrm{Sb}$; 3) no significant correlations with $\mathrm{Cu}, \mathrm{Cd}, \mathrm{Ba}, \mathrm{Co}, \mathrm{Zn}, \mathrm{Sn}, \mathrm{Ni}, \mathrm{As}$, $\mathrm{Pb}$ and $\mathrm{Fe}$. Considering the clay and fine silt percentages together, correlations with heavy metals do not improve and follow the same pattern as that with the clay percentage alone.

Results of the statistical analyses have shown a large variety and complexity in these relationships. Nevertheless, the main trends described in the literature, such as positive correlations with organic matter and negative with $\mathrm{pH}$ (e.g. Labib et al., 1989) have also been observed with most of the studied heavy metals.

\section{2.- Spatial distribution of heavy metals.}

From the maps of contents of heavy metals a large spatial variability in their distribution has been observed (Figure 5). This variability is mainly due to diversity in soil types and parent materials and related edaphic and weathering processes.

The heavy metals present in natural soils derive from weathering of parent materials and subsequent pedogenesis (Aubert and Pinta, 1977; Vaselli et al., 1997). Haynes (1997) points out the role of soil development in the leaching and/or inmobilization of some metals. To assess the effects of soil type and parent materials on the variation of the heavy metal contents in the studied soils, an analysis of variance has been applied. The following factorial model of fixed effects (General Linear Model Procedures, SAS) has been used:

$$
\mathrm{Y}_{\mathrm{ijk}}=\mu+\text { soil type }_{\mathrm{i}}+\text { parent materials }_{\mathrm{j}}+\mathrm{E}_{\mathrm{ijk}}
$$

Where $\mathrm{Y}=$ observed value for the analysed variable, $\mu=$ population mean, $\mathrm{E}=$ residual error, $\mathrm{ijk}=$ variation levels of the factors ( 9 soil types, 10 bedrock types). As can be seen in Table 5, Cd, Ba, Co, $\mathrm{Zn}, \mathrm{Sn}, \mathrm{As}, \mathrm{Pb}$ and $\mathrm{Mn}$ are not affected by the soil type. Similarly parent materials did not affect $\mathrm{Cr}, \mathrm{Ba}, \mathrm{Zn}, \mathrm{Sn}, \mathrm{As}, \mathrm{Pb}$ and $\mathrm{Al}$ but significantly affected the variations of the remaining heavy metals. This analysis showed that, both soil types and parent materials have an effect on the variations of most heavy metals, although parent materials appear to be of greater effect on such variations. 
To produce the maps of isolevels of heavy metal contents at a scale of $1 / 500,000$ (Figure 5) we have chosen a non regular scale with an increasing interval to highlight the low heavy metal contents. The soils with lower metal contents are Gypsisols and Calcisols that are predominant in the lowlands of the Ebro depression plains. Leptosols exhibit the highest contents for all the heavy metals and predominate in the uplands.

In the Iberian and Pyrenees mountain ranges, more bedrock variability comprising metamorphic, granitic and volcanic, with some primary metal rich minerals included in their mineralogical composition together with non developed soil types, result in the highest contents of heavy metals found in this study. In the central Ebro valley, the contents of heavy metals are much lower. This also can be a result of the rock and the soil types. These are developed on evaporitic lithologies (carbonates and gypsum) with low mineral diversity and a soil composition that hardly retains trace elements. Nevertheless, neither marked geochemically anomalous areas of soils within the Aragón region nor areas were trace-element deficiency can be a problem for agriculture have been found. Although in the region induced deficiencies of $\mathrm{Zn}, \mathrm{Fe}$ and Mn have been reported in cultivated soils by Millán et al. (1983), these deficiencies are not caused by the low contents of these elements but due to the combined effect of high $\mathrm{pH}$ and carbonates and low soil porosity.

\section{4.- Conclusions}

This study has highlighted the need for further research, by increasing sampling density to better characterize the heavy metal contents in the soils of Aragón as a function of their physical and chemical characteristics, pedogenetic processes and parent materials. The influence of bedrock on the heavy metal contents in the studied soils seems to be more pronounced than that of pedogenesis.

The results obtained served to increase our knowledge on the heavy metal composition of the studied soil types and are a first approach to establish the environmental levels of various elements. The data will be of use for further detailed studies in the region as well as to complement other geochemical databases. This work will be the basis to define the requirements for further research in order to better establish permitted levels of metals for soil conservation, as well as to identify areas of potential toxicity due to heavy metal participation in biogeochemical cycles. Our results 
can also supply information for the agricultural user on the micronutrient soil levels as well as for land use planning.

The use of IDRISI GIS software package has proved to be cost-effective and a powerful technique for processing the large database on the studied soils that has been compiled for producing geochemical maps of the analysed elements in the soils of Aragón.

\section{References}

Aubert, H. \& Pinta, M. 1977. Trace elements in soils. Elsevier. Amsterdam. 395 pp.

Berry, J.K. 1987. Fundamental operations in computer assisted map analysis. Int. J. Geographical Information Systems 1, 119-136.

Boluda Hernández, R., Andreu Pérez, V., Pons Martí, V., Sánchez Díaz, J. 1988. Heavy metals contents $(\mathrm{Cd}, \mathrm{Co}, \mathrm{Cr}, \mathrm{Cu}, \mathrm{Ni}, \mathrm{Pb}$ and $\mathrm{Zn})$ in soils of the Plana Requena Utiel region (Valencia). Anales de Edafología y Agrobiología, 47, 1485-1502.

Brümmner, G.W., Herth, J., Herms, U. 1986. Heavy metals species, mobility and availability in soils. Z. Pflanzenernähr. Bodenkd. 149, 382-398.

Burrough, P.A. 1986. Principles of geographical information systems for land resources assessment. Clarendon Press, University Press. Oxford. 193 pp.

FAO, 1989. Mapa mundial de suelos. Leyenda revisada. Roma.

González García, F., García Gómez, A.M. 1964. Geoquímica del cobalto en los suelos de Andalucía occidental. I- Contenido en cobalto total y caracteres generales de los suelos del valle del Guadalquivir. Anales de Edafología y Agrobiología, XXIII, 1-2, 314-321.

Haynes, R.J. 1997. Micronutrient status of a group of soils in Canterbury, New Zealand, as measured by extraction with EDTA, DTPA and $\mathrm{HCl}$, and its relationship with plant response to applied $\mathrm{Cu}$ and $\mathrm{Zn}$. Journal of Agricultural Science, 129, 325-333. 
Jones, L.H.P., Jarvis, S.C. 1981. The fate of heavy metals. In: D.J. Greenland and M.H.B. Hayes (eds.). The Chemistry of Soil Processes, pp. 593-620 . Wiley and Sons. New York. USA

Jordan , C., Cruickshank, J.G., Higgins, A.J., Hamill, K.P. 1997. The soil geochemical atlas of Northern Ireland. Department of Agriculture for Northern Ireland. Belfast. UK

Kabata-Pendias, A., Pendias, H. 1984. Trace elements in Soils and Plants. Boca Raton, Florida: CRC Press. 315 pp.

Kinniburgh, D.G., Beckett, P.H.T. 1983. Geochemical mapping in Oxfordshire: a comparison of stream sediment and soil sampling. J. Soil Sci. 34, 183-203.

Labib, F.B., Khalil, J.B., Halaka, S.H. 1989. Heavy metals in some soils and clay beds of Bahariya Oasis, Egypt. Agrochimica, 33, 75-84.

Machín, J. 1984. Mapa de suelos de Aragón (1:500.000). (Unpublished).

McKenzie, R. M. 1959. Trace elements in some South Australian terra rossa and rendzina soils. Aust. J. Agric. Res. 10, 52-57.

McGrath, S.P., Loveland P.J. 1992. The Geochemical Atlas of England and Wales. Chapman and Hall, London. 102 pp.

Millán, E., Abadía, A., Montañés, L. 1983. Niveles de Fe, Mn, Cu y Zn en suelos cultivados del valle del Ebro. An. Aula Dei. 16, 305-317.

Polemio, M., Rhoades , J.D. 1977. Determining cation exchange capacity : A new procedure for calcareous and gypsiferous soils. Soil Sci. Soc. Am. J. 41, 524-528.

Rogowski, A.S. 1996. Quantifying soil variability in GIS applications: II. Spatial distribution of soil properties. Int. J. Geographical Information Systems 10, 455- 475. 
Rose, A.W., Hawkes, H.E., Webb, J.S. 1979. Geochemistry in mineral exploration. $2^{\text {nd }}$ edn. London: Academic Press.

Vaselli, O., Buccianti, A, De Siena, C., Bini, C. Coradossi, N., Angelone, M. 1997. Geochemical characterization of ophiolitic soils in a temperate climate: a multivariate statistical approach. Geoderma, 75, 117-133.

Webb, J.S., Thornton, I. Thomson, M., Howarth, R.J., Lowenstein, P.L. 1978. The Wolfson Geochemical Atlas of England and Wales. Oxford: Clarendon Press.

Wilcke, W., Kretzschmar, S., Bundt, M. Saborío, G., Zech, W. 1998. Aluminum and heavy metal partitioning in A horizons of soils in Costa Rican coffee plantations. Soil Science 163, 463-471.

Wopereis, M.C., Gascuel-Odoux, C., Bourrie, G., Soignet, G., 1988. Spatial variability of heavy metals in soil on a one-hectare scale. Soil Science 146, 113-118. 


\section{FIGURES}

1.- Location of the study area, soil types, topography, annual rainfall and distribution of sampling sites.

2.- Box and whisker plots of $\mathrm{Cr}, \mathrm{Cu}, \mathrm{Ni}, \mathrm{Sn}, \mathrm{Pb}, \mathrm{Co}, \mathrm{Zn}$ and $\mathrm{Cd}$ contents $(\mathrm{mg} / \mathrm{kg}$ ) for each studied soil type (the lower boundary of the box is the $25^{\text {th }}$ percentile, the upper boundary is the $75^{\text {th }}$ percentile, the vertical line inside the box represents the median, mean is plotted as the small vertical line, individual points are outliers).

3.- Box and whisker plots of $\mathrm{Ba}, \mathrm{As}, \mathrm{Sb}, \mathrm{Fe}, \mathrm{Al}$ and $\mathrm{Mn}$ contents $(\mathrm{mg} / \mathrm{kg})$ for each studied soil type (the lower boundary of the box is the $25^{\text {th }}$ percentile, the upper boundary is the $75^{\text {th }}$ percentile, the vertical line inside the box represents the median, mean is plotted as the small vertical line, individual points are outliers).

4.- Spatial distribution of $\mathrm{pH}$, organic matter, cation exhange capacity, and clay content in the studied soils of Aragón mapped by geostatistical interpolation using IDRISI GIS.

5.- Spatial distribution of heavy metal contents in the studied soils of Aragón mapped by geostatistical interpolation using IDRISI GIS.

\section{TABLES}

1.- Selected soil types, relative surface area and number of sampling sites.

2.- Descriptive basic statistics of the heavy metals contents in the studied soils.

3.- Correlations between the heavy metal contents $(\mathrm{mg} / \mathrm{kg})$ in the studied soils. Spearman and Pearson coefficients are shown above and below the diagonal line, respectively. Statistical significance: $\mathrm{ns}=$ not significant; $*=\mathrm{p} \leq 0.05 ; * *=\mathrm{p} \leq 0.01$; $* * *=\mathrm{p} \leq 0.001$.

4.- Pearson correlations between organic matter (\%), cation exchange capacity (CEC, $\mathrm{meq} / 100 \mathrm{~g})$, $\mathrm{pH}$, clay and fine silt percentages with the heavy metal contents $(\mathrm{mg} / \mathrm{kg})$ in the studied soils. Statistical significance: $\mathrm{ns}=$ not significant; $*=\mathrm{p} \leq 0.05 ; * *=\mathrm{p} \leq$ $0.01 ; * * * \mathrm{p} \leq 0.001$.

5.- Effect of soil and bedrock types on the heavy metal contents analysed by using a factorial model of fixed effects (General Linear Model Procedures, SAS). Statistical significance: $\mathrm{ns}=$ not significant; $*=\mathrm{p} \leq 0.05 ; * *=\mathrm{p} \leq 0.01 ; * * *=\mathrm{p} \leq 0.001$. 
Table 1

\begin{tabular}{|c|c|c|}
\hline $\begin{array}{l}\text { Soil groups } \\
\text { (FAO, 1989) }\end{array}$ & $\begin{array}{c}\text { Surface } \\
\% \\
\end{array}$ & $\begin{array}{c}\text { Samples } \\
\mathbf{n}\end{array}$ \\
\hline Fluvisols & 5.1 & 6 \\
\hline Regosols & 11.0 & 18 \\
\hline Gypsisols & 3.5 & 7 \\
\hline Leptosols & 14.6 & 17 \\
\hline Solonchaks + Solonetzs & 1.8 & 6 \\
\hline Calcisols & 20.7 & 27 \\
\hline Kastanozems & 17.1 & 19 \\
\hline Phaeozems & 3.2 & 5 \\
\hline Cambisols & 20.5 & 28 \\
\hline
\end{tabular}


Table 2

\begin{tabular}{|c|c|c|c|c|c|c|c|c|c|c|c|c|c|}
\hline & $\mathrm{Cr}$ & $\mathrm{Cu}$ & Cd & $\mathrm{Ba}$ & Co & $\mathrm{Zn}$ & $\begin{array}{r}\mathrm{Sn} \\
\mathrm{mg} / \mathrm{kg}\end{array}$ & $\mathrm{Ni}$ & As & $\mathbf{P b}$ & $\mathrm{Fe}$ & Al & Mn \\
\hline $\begin{array}{l}\text { Sample size = } 133 \\
\text { Mean }\end{array}$ & 21.0 & 10.3 & 0.75 & 117.7 & 7.0 & 55.6 & 8.5 & 19.3 & 11.8 & 8.3 & 16868 & 19977 & 320.7 \\
\hline Median & 19.2 & 8.4 & 0.46 & 100.0 & 5.9 & 48.2 & 2.2 & 17.4 & 11.5 & 5.9 & 15900 & 18750 & 284.0 \\
\hline Variance & 153.5 & 68.8 & 0.76 & 11125.6 & 23.5 & 3166.4 & 373.5 & 347.2 & 117.9 & 185.6 & 58327000 & 75812400 & 50197.8 \\
\hline Standard deviation & 12.4 & 8.3 & 0.87 & 105.5 & 4.9 & 56.3 & 19.3 & 18.6 & 10.9 & 13.6 & 7637 & 8707 & 224.0 \\
\hline Standard error & 1.1 & 0.7 & 0.08 & 9.1 & 0.4 & 4.9 & 1.7 & 1.6 & 0.9 & 1.2 & 662 & 755 & 19.4 \\
\hline Minimum & 2.3 & 0.7 & BDL & 20.3 & BDL & 6.5 & $\mathrm{BDL}$ & 2.3 & BDL & BDL & 580 & 1160 & 7.4 \\
\hline Maximum & 95.3 & 58.2 & 4.55 & 979.0 & 45.0 & 626.0 & 160.2 & 210.0 & 58.9 & 146.0 & 42110 & 52670 & 2136.0 \\
\hline Range & 93.0 & 57.5 & 4.55 & 958.7 & 45.0 & 619.5 & 160.2 & 207.7 & 58.9 & 146.0 & 41530 & 51510 & 2128.6 \\
\hline Lower quartile & 13.6 & 5.9 & 0.00 & 77.4 & 4.7 & 30.3 & 0.1 & 11.9 & 2.3 & 3.0 & 11290 & 14310 & 204.0 \\
\hline Upper quartile & 24.1 & 11.4 & 1.17 & 134.0 & 8.0 & 65.3 & 8.9 & 22.2 & 15.8 & 10.0 & 20160 & 23610 & 385.0 \\
\hline Interquartile range & 10.5 & 5.5 & 1.17 & 56.6 & 3.3 & 35.0 & 8.8 & 10.3 & 13.5 & 7.0 & 8870 & 9300 & 181.0 \\
\hline Coeff. of variation \% & 59 & 80 & 117 & 89 & 69 & 101 & 228 & 96 & 92 & 163 & 45 & 44 & 69 \\
\hline
\end{tabular}




\section{Table 3}

\begin{tabular}{|c|c|c|c|c|c|c|c|c|c|c|c|c|c|c|}
\hline & $\mathrm{Cr}$ & Su & d & $\mathrm{Ba}$ & Eo & $\mathrm{Zn}$ & Sn & $\mathrm{Ni}$ & As & Sb & $\mathrm{Pb}$ & $\mathrm{Fe}$ & Al & In \\
\hline $\mathrm{Cr}$ & 1 & & & & & & & & & & & & & \\
\hline $\mathrm{Cu}$ & & 1 & & & & & $\begin{array}{c}0.077 \\
\text { ns }\end{array}$ & & & $\begin{array}{c}-0.003 \\
n s\end{array}$ & & & & \\
\hline Cd & & & 1 & & & 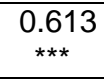 & & 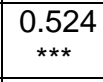 & $\begin{array}{c}0.273 \\
* * \\
\end{array}$ & & & 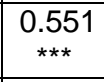 & $\begin{array}{c}0.204 \\
\star\end{array}$ & $\begin{array}{c}0.437 \\
\star \star \star \star \\
\end{array}$ \\
\hline Ba & & & & 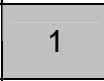 & 0.403 & $\begin{array}{c}0.402 \\
\star \star \star \star\end{array}$ & & $\begin{array}{c}0.330 \\
\star \star \star\end{array}$ & 0.226 & & & $\begin{array}{c}0.376 \\
\star \star \star \star\end{array}$ & & $\begin{array}{c}0.320 \\
\star \star \star\end{array}$ \\
\hline Co & & & & & 1 & $\begin{array}{c}0.725 \\
\star \star \star \star\end{array}$ & & $\underset{\star c * \star}{0.867}$ & & & & & $\begin{array}{c}0.756 \\
\star \star \star\end{array}$ & $\underset{\star x \star *}{0.734}$ \\
\hline $\mathrm{Zn}$ & & & 0.524 & & & 1 & & & & & & & 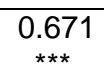 & 0.696 \\
\hline & & & & & & & & $\begin{array}{c}0.030 \\
\mathrm{~ns}\end{array}$ & \begin{tabular}{|c}
-0.021 \\
$n s$
\end{tabular} & $\begin{array}{c}-0.028 \\
\text { ns }\end{array}$ & & & & $\begin{array}{c}0.092 \\
\text { ns }\end{array}$ \\
\hline $\mathrm{Ni}$ & 0.341 & & 0.588 & & & 0.286 & & 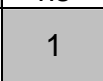 & $\begin{array}{c}0.438 \\
\star \star \star\end{array}$ & & & 0.938 & ${ }_{\star \star \star \star}^{0.816}$ & 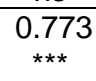 \\
\hline$\Delta c$ & 0.448 & 0.217 & & $\begin{array}{c}-0.020 \\
\text { ns }\end{array}$ & & $\underset{* * *}{0.354}$ & $\begin{array}{c}-0.011 \\
\text { ns } \\
\end{array}$ & $\begin{array}{c}0.150 \\
n s\end{array}$ & 1 & \begin{tabular}{|c}
-0.122 \\
ns \\
\end{tabular} & & $\underset{* \star \star}{0.418}$ & $\underset{* \star \star}{0.447}$ & $\underset{* \star 373}{0.373}$ \\
\hline & 0.059 & & $\begin{array}{c}0.394 \\
* \star \star\end{array}$ & $\begin{array}{c}-0.010 \\
n s\end{array}$ & $\begin{array}{c}0.713 \\
\star \star \star \star\end{array}$ & 0.136 & $\begin{array}{c}-0.017 \\
n s\end{array}$ & $\begin{array}{c}0.892 \\
\star \star \star\end{array}$ & $\begin{array}{c}-0.085 \\
\text { ns }\end{array}$ & 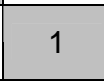 & & $\begin{array}{c}0.018 \\
\text { ns }\end{array}$ & $\begin{array}{c}0.002 \\
\text { ns }\end{array}$ & $0.10 s$ \\
\hline & $\begin{array}{c}0.168 \\
*\end{array}$ & & $\begin{array}{c}0.439 \\
\star \star \star \star\end{array}$ & 0.043 & 0.413 & $\underset{\star \star \star \star}{0.907}$ & $\begin{array}{c}-0.057 \\
\text { ns }\end{array}$ & 0.147 & $\begin{array}{c}0.314 \\
* \star \star\end{array}$ & & & 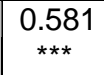 & $\underset{\star \star \star}{0.389}$ & $\underset{* \star \star}{0.58 \varepsilon}$ \\
\hline & & & 0.683 & 0.057 & $\begin{array}{c}0.813 \\
* \star \star\end{array}$ & $\begin{array}{c}0.504 \\
\star \star \star \star\end{array}$ & & 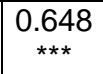 & $\begin{array}{c}0.483 \\
\star \star \star\end{array}$ & $\underset{* \star \star}{0.298}$ & & $\perp$ & $\begin{array}{c}0.796 \\
\star \star \star \star\end{array}$ & $\begin{array}{c}0.766 \\
\star \star \star \star\end{array}$ \\
\hline Al & & 0.420 & $\begin{array}{c}0.254 \\
\star \star \star \star\end{array}$ & $\begin{array}{c}0.115 \\
\text { ns }\end{array}$ & $\begin{array}{c}0.563 \\
\star \star \star \star\end{array}$ & $\begin{array}{c}0.361 \\
\star \star \star \star\end{array}$ & & & $\underset{\star \star \star 5 * \star}{0.514}$ & $\begin{array}{c}0.035 \\
\text { ns }\end{array}$ & & $\begin{array}{c}0.759 \\
\star \star \star\end{array}$ & 1 & $\begin{array}{c}0.627 \\
* * \star\end{array}$ \\
\hline & $\begin{array}{c}0.374 \\
\star \star \star \star\end{array}$ & $\begin{array}{c}0.378 \\
\star \star \star \star\end{array}$ & 0.423 & $\begin{array}{c}0.086 \\
\text { ns }\end{array}$ & $\begin{array}{c}0.505 \\
\star \star \star *\end{array}$ & $\begin{array}{c}0.469 \\
\star \star \star \star\end{array}$ & $\begin{array}{c}0.027 \\
n s\end{array}$ & $\begin{array}{c}0.332 \\
\star \star \star\end{array}$ & $\underset{\star \star \star 2}{0.297}$ & $\begin{array}{c}0.058 \\
\text { ns }\end{array}$ & & 0.665 & & \\
\hline
\end{tabular}




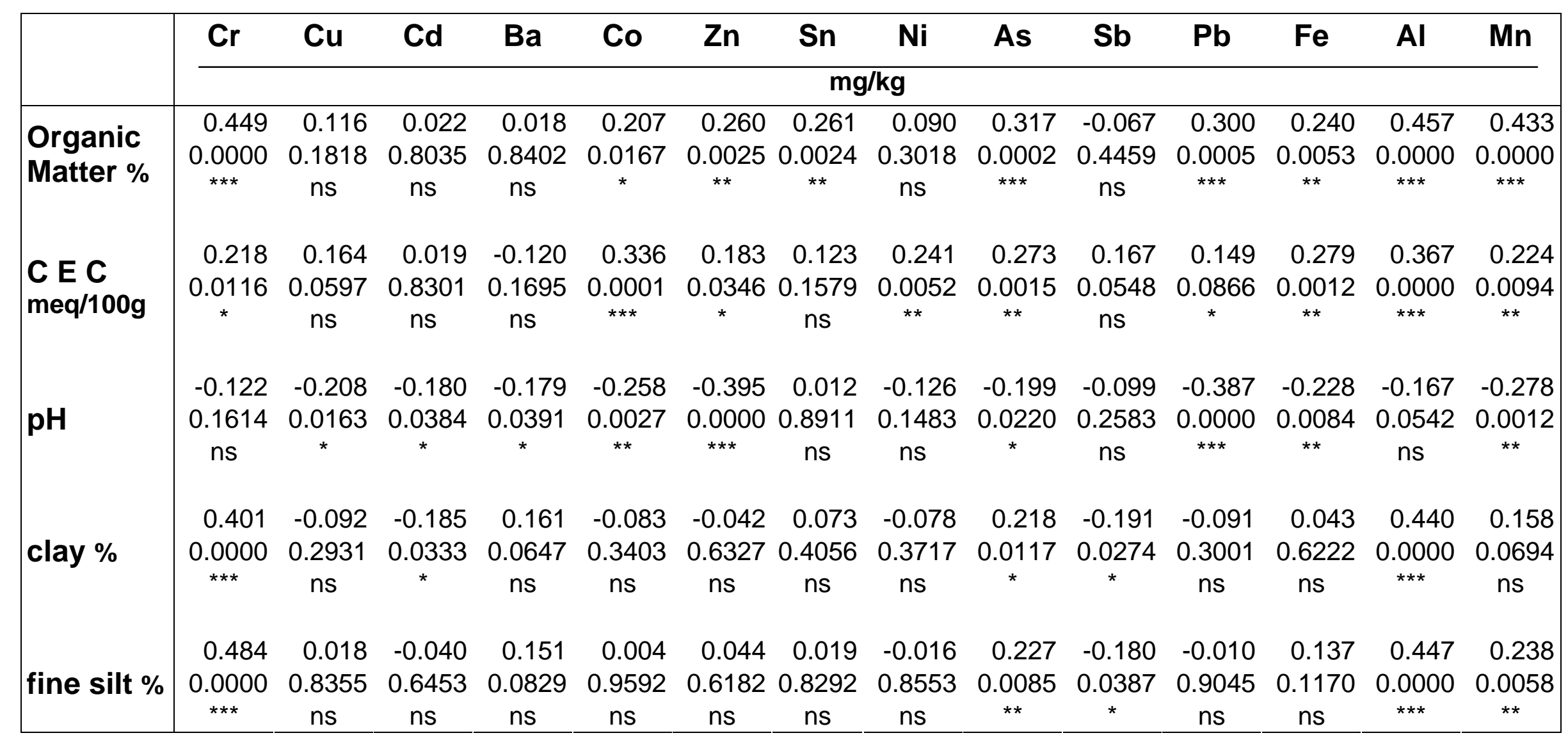




\begin{tabular}{|c|c|c|c|c|c|c|c|c|c|c|c|c|c|c|}
\hline & $\mathrm{Cr}$ & $\mathrm{Cu}$ & Cd & $\mathrm{Ba}$ & Co & $Z n$ & Sn & $\mathrm{Ni}$ & As & Sb & $\mathbf{P b}$ & $\mathrm{Fe}$ & Al & Mn \\
\hline & \multicolumn{14}{|c|}{$\mathrm{mg} / \mathrm{kg}$} \\
\hline Organic & 0.449 & 0.116 & 0.022 & 0.018 & 0.207 & 0.260 & 0.261 & 0.090 & 0.317 & -0.067 & 0.300 & 0.240 & 0.457 & 0.433 \\
\hline Matter \% & $\star * \star$ & ns & ns & ns & * & $\star *$ & $\star \star$ & ns & 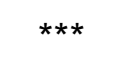 & ns & $\star * *$ & $\star *$ & $\star \star *$ & $\star \star \star ~$ \\
\hline $\begin{array}{l}\text { C E C } \\
\mathrm{meq} / 100 \mathrm{~g}\end{array}$ & $\begin{array}{c}0.218 \\
*\end{array}$ & $\begin{array}{l}0.164 \\
\text { ns }\end{array}$ & $\begin{array}{l}0.019 \\
\text { ns }\end{array}$ & $\begin{array}{c}-0.120 \\
n s\end{array}$ & $\begin{array}{l}0.336 \\
\star * \star\end{array}$ & $\begin{array}{c}0.183 \\
*\end{array}$ & $\begin{array}{c}0.123 \\
\text { ns }\end{array}$ & $\begin{array}{c}0.241 \\
\star *\end{array}$ & $\begin{array}{c}0.273 \\
\star *\end{array}$ & $\begin{array}{l}0.167 \\
\text { ns }\end{array}$ & $\begin{array}{c}0.149 \\
*\end{array}$ & $\begin{array}{c}0.279 \\
\star \star\end{array}$ & $\begin{array}{l}0.367 \\
* * *\end{array}$ & $\begin{array}{l}0.224 \\
\star *\end{array}$ \\
\hline pH & $\begin{array}{c}-0.122 \\
n s\end{array}$ & $\begin{array}{c}-0.208 \\
*\end{array}$ & $\begin{array}{c}-0.180 \\
*\end{array}$ & $\begin{array}{c}-0.179 \\
*\end{array}$ & $\begin{array}{c}-0.258 \\
\star *\end{array}$ & $\begin{array}{l}-0.395 \\
\star \star \star\end{array}$ & $\begin{array}{c}0.012 \\
\text { ns }\end{array}$ & $\begin{array}{c}-0.126 \\
n s\end{array}$ & $\begin{array}{c}-0.199 \\
*\end{array}$ & $\begin{array}{c}-0.099 \\
n s\end{array}$ & $\begin{array}{c}-0.387 \\
\star \star \star\end{array}$ & $\begin{array}{c}-0.228 \\
\star \star\end{array}$ & $\begin{array}{c}-0.167 \\
\mathrm{~ns}\end{array}$ & $\begin{array}{c}-0.278 \\
\star \star\end{array}$ \\
\hline clay \% & $\begin{array}{l}0.401 \\
\star * \star\end{array}$ & $\begin{array}{c}-0.092 \\
\text { ns }\end{array}$ & $\begin{array}{c}-0.185 \\
*\end{array}$ & $\begin{array}{l}0.161 \\
\text { ns }\end{array}$ & $\begin{array}{c}-0.083 \\
n s\end{array}$ & $\begin{array}{c}-0.042 \\
n s\end{array}$ & $\begin{array}{c}0.073 \\
\text { ns }\end{array}$ & $\begin{array}{c}-0.078 \\
n s\end{array}$ & $\begin{array}{c}0.218 \\
*\end{array}$ & $\begin{array}{c}-0.191 \\
*\end{array}$ & $\begin{array}{c}-0.091 \\
\text { ns }\end{array}$ & $\begin{array}{l}0.043 \\
\text { ns }\end{array}$ & $\begin{array}{l}0.440 \\
* * \star\end{array}$ & $\begin{array}{l}0.158 \\
\text { ns }\end{array}$ \\
\hline fine silt \% & $\begin{array}{l}0.484 \\
\star \star *\end{array}$ & $\begin{array}{l}0.018 \\
\text { ns }\end{array}$ & $\begin{array}{c}-0.040 \\
n s\end{array}$ & $\begin{array}{l}0.151 \\
\mathrm{~ns}\end{array}$ & $\begin{array}{l}0.004 \\
\text { ns }\end{array}$ & $\begin{array}{l}0.044 \\
\text { ns }\end{array}$ & $\begin{array}{c}0.019 \\
\text { ns }\end{array}$ & $\begin{array}{c}-0.016 \\
n s\end{array}$ & $\begin{array}{c}0.227 \\
\star \star\end{array}$ & $\begin{array}{c}-0.180 \\
*\end{array}$ & $\begin{array}{c}-0.010 \\
n s\end{array}$ & $\begin{array}{l}0.137 \\
\text { ns }\end{array}$ & $\begin{array}{l}0.447 \\
\star \star \star\end{array}$ & $\begin{array}{c}0.238 \\
\star *\end{array}$ \\
\hline
\end{tabular}


Table 5

\begin{tabular}{|c|c|c|c|c|c|c|c|c|c|c|c|c|c|}
\hline & $\mathrm{Cr}$ & $\mathrm{Cu}$ & Cd & $\mathrm{Ba}$ & Co & $\mathrm{Zn}$ & $\begin{array}{c}\text { Sn } \\
\mathrm{mg} / \mathrm{kg}\end{array}$ & $\mathrm{Ni}$ & As & $\mathrm{Pb}$ & $\mathrm{Fe}$ & Al & Mn \\
\hline $\mathbf{R}^{2}$ & 0.297 & 0.522 & 0.358 & 0.129 & 0.669 & 0.179 & 0.155 & 0.865 & 0.204 & 0.176 & 0.379 & 0.307 & 0.293 \\
\hline Soil type & $* *$ & $* * *$ & ns & ns & ns & ns & ns & ** & ns & ns & * & ** & ns \\
\hline Bedrocks & ns & $* * *$ & $* * *$ & ns & $* \star *$ & ns & ns & *** & ns & ns & ** & ns & * \\
\hline \multicolumn{14}{|c|}{ Statistical significance } \\
\hline & & & & & s & * & & & & & & & \\
\hline
\end{tabular}




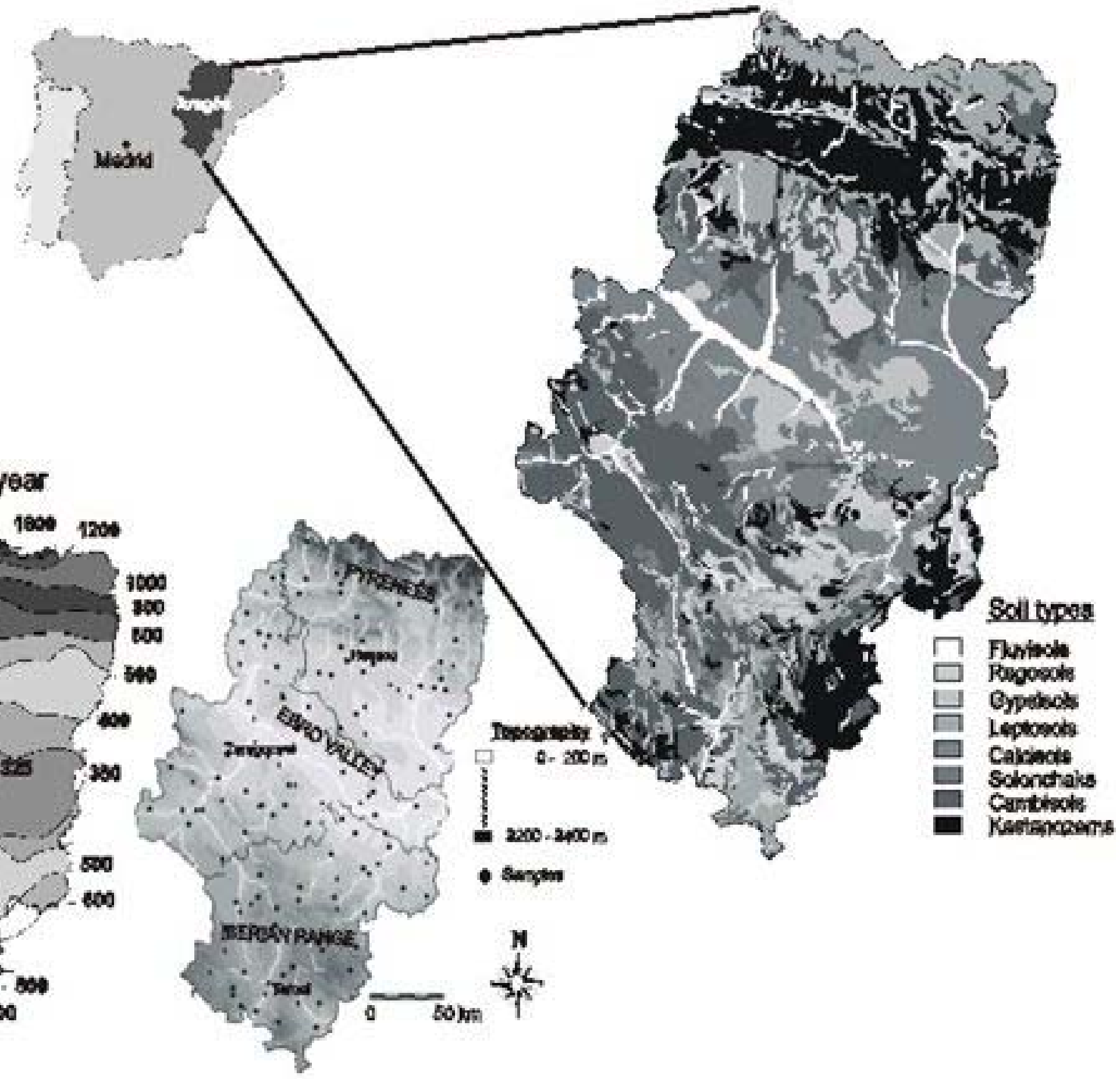




\section{Fig. 5}
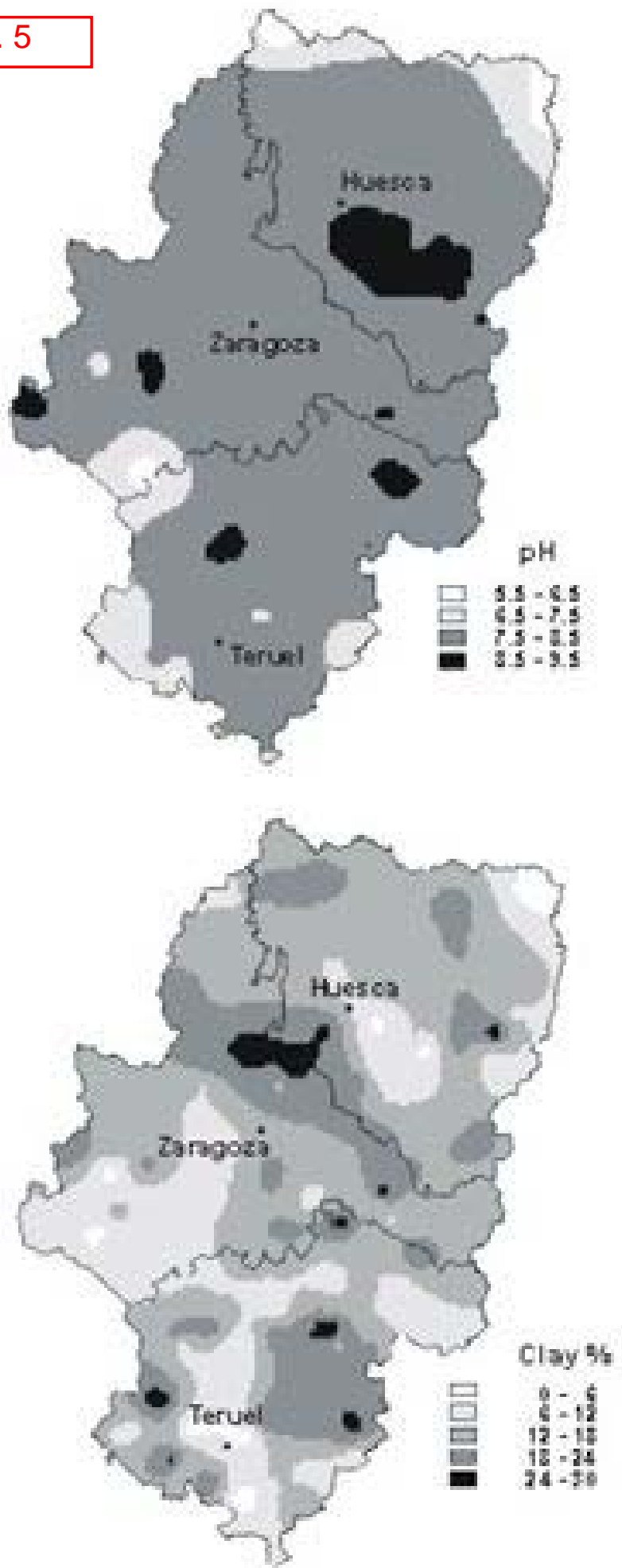
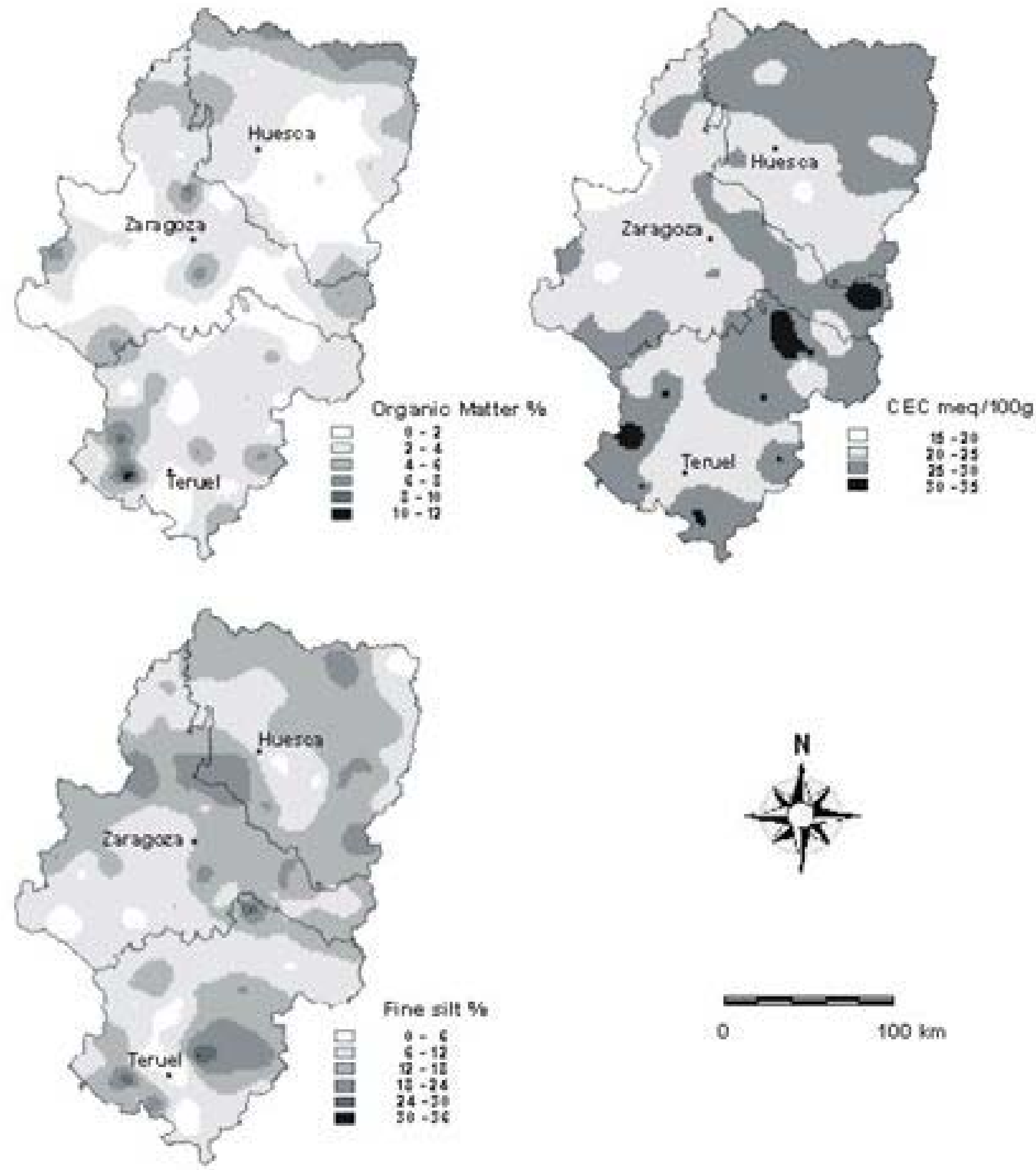

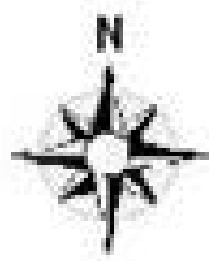

0 $100 \mathrm{~km}$ 